\title{
Estudo taxonômico de Sapotaceae Juss. do litoral Paraense
}

\author{
Deyvid Marques VALENTE ${ }^{1}$, Julio dos Santos de SOUSA², Maria de Nazaré do Carmo BASTOS 3 \\ RESUMO \\ Este trabalho consiste no tratamento taxonômico de Sapotaceae Juss. nas restingas do litoral paraense. Com auxilio de \\ estereomicroscópio foram feitas as descriçóes morfológicas das partes vegetativas e reprodutivas. Utilizou-se literatura \\ especializada, coleçóes identificadas por especialistas para confirmar as características diferenciais dos táxons e montada uma \\ chave de identificação para as espécies. Foram descritas cinco espécies e quatro subespécies, distribuídas em quatro gêneros: \\ Manilkara bidentata subsp. bidentata, $M$. bidentata subsp. surinamensis, M. triflora, M. paraensis; Micropholis venulosa, $M$. \\ gnaphaloclados; Pouteria ramiflora, P. reticulata subsp. reticulata and Pradosia schomburgkiana subsp. schomburgkiana. O \\ gênero Manilkara Adans. foi o mais representativo com duas espécies e duas subespécies. A formação floresta de restinga foi \\ o ecossistema que apresentou o maior número de táxons.
}

PALAVRAS-CHAVE: Amazônia, taxonomia, morfologia

\section{The taxonomic study of the Sapotaceae Juss. on the coast of Pará}

\section{ABSTRACT}

This study deals with the taxonomic treatment of Sapotaceae Juss. on the coastal sandbanks of Pará State. With the aid of a stereomicroscopy, there were made morphological descriptions of reproductive and vegetative parts. We used literature and collections identified by specialists to confirm the different characteristics of the taxa. We also constructed an identification key for species. We described five species and four subspecies, distributed into four genera: Manilkara bidentata subsp. bidentata, M. bidentata subsp. surinamensis, M. triflora, M. paraensis; Micropholis venulosa, M. gnaphaloclados; Pouteria ramiflora, P. reticulata subsp. reticulata and Pradosia schomburgkiana subsp. schomburgkiana. The genus Manilkara Adans. was the most representative with two species and two subspecies. The sandbank forest formation was the ecosystem with the largest number of taxa.

KEYWORDS: Amazonia, taxonomy, morphology

${ }^{1}$ Museu Paraense Emílio Goeldi - MCT, Campus de Pesquisa, Coordenação de Botânica, Av. Perimetral, 1901, Terra Firme, Belém-PA, CEP. 66017-970, fone: (91) 3217-6073. E-mail: deykkcaos@hotmail.com. Bolsista PIBIC/CNPq/Museu Paraense Emílio Goeldi.

2 Museu Paraense Emílio Goeldi - MCT, Campus de Pesquisa, Coordenação de Botânica, Av. Perimetral, 1901, Terra Firme, Belém-PA, CEP. 66017-970, fone: (91) 3217-6073. E-mail: jssousa27@yahoo.com.br. PPGBionorte/CNPq/MPEG.

${ }^{3}$ Museu Paraense Emílio Goeldi - MCT, Campus de Pesquisa, Coordenação de Botânica, Av. Perimetral, 1901, Terra Firme, Belém-PA, CEP. 66017-970, fone: (91) 3217-6073. E-mail: nazir@museu-goeldi.br. 


\section{INTRODUÇÃO}

$\mathrm{Na}$ Amazônia brasileira, as restingas ocupam uma área de aproximadamente $1.000 \mathrm{~km}^{2}$, correspondendo a menos de $0,1 \%$ dos demais tipos de vegetação ocorrentes na região (Amaral et al. 2008). Apesar da riqueza de espécies desse ambiente, ainda são poucos os estudos taxonômicos nesse ecossistema.

Somente em 1999 iniciaram-se estudos taxonômicos, mediante a elaboração da flórula fanerogâmica das restingas do estado do Pará, com o tratamento da família Turneraceae A.P. de Candolle, ocorrente na restinga da Princesa, em Algodoal, Maracanã-PA (Vicente et al. 1999). Em seguida, Rocha e Bastos (2004), as Eriocaulaceae; Rosário et al. (2005), as Myrtaceae; Margalho et al. (2009), as Rubiaceae e Sousa et al. (2009), as Leguminosae-Mimosoideae. Dando prosseguimento ao estudo dessa flórula, faz-se necessário o tratamento de Sapotaceae Jss.

No Brasil, Sapotaceae está representada por 11 gêneros, 227 espécies e 32 subespécies, sendo 104 táxons endêmicos (Carneiro et al. 2012). É uma das famílias mais importantes (riqueza e abundância) de florestas ombrófilas da Amazônia, onde seus representantes são utilizados na produção de goma comercial, madeira de qualidade, matéria-prima para especiarias e frutos comestíveis (Pennington 1990).

A família pertence à ordem Ericales (APG III 2009), anteriormente posicionada em Ebenales. Entretanto, o estudo dos gêneros ainda apresenta lacunas, o que torna a circunscrição dos mesmos complexa.

Nesse aspecto, levando em conta os problemas taxonômicos apresentados pelo grupo e a escassez de estudos na área, optouse pelo tratamento taxonômico de Sapotaceae das restingas do estado do Pará, fornecendo informaçôes para uma melhor identificação dos táxons e subsídios aos planos de manejo das áreas de proteção ambiental (APAs) deste ecossistema.

\section{MATERIAL E MÉTODOS}

\section{Localização e caracterização da área de estudo}

A zona litorânea do Estado do Pará, com cerca de 500 km integram a planície costeira do Nordeste do Pará, situada entre a baía do Marajó $0^{\circ}$. $30^{\prime} \mathrm{S}$ e $46^{\circ} 00 \mathrm{~W}$ Gr. e a baia do Gurupí $0^{\circ}$. 30' S e 46.00 W Gr. (Bastos et al. 2002). A cobertura vegetal das restingas do Estado do Pará está distribuída em seis formaçóes vegetais distintas: halófila, psamófila reptante, brejo herbáceo, campo de dunas, formação aberta de moitas e floresta de restinga (Amaral et al. 2008).

O estudo foi baseado em material herborizado, a maioria proveniente de coletas efetuadas pelos autores, incorporado nos herbários do Museu Paraense Emílio Goeldi (MG) e da Empresa Brasileira de Pesquisa Agropecuária/
Embrapa Amazônia Oriental, Belém, Pará, Brasil (IAN). A terminologia utilizada para as estruturas morfológicas está baseada nos trabalhos de Hickey (1973), Rizzini (1977) e Pennington (1990). A identificação dos táxons foi realizada por comparação com o material herborizado, muito deles certificados por especialistas, análise dos tipos, quando disponíveis, chaves analíticas, diagnoses e descriçôes existentes na literatura. As ilustraçóes foram feitas com o auxílio de câmara clara acoplada a estereomicroscópio. Neste trabalho, foi utilizado o sistema APG III, que posiciona Sapotaceae na ordem Ericales, pertencente ao grupo das Asterídeas.

\section{RESULTADOS E DISCUSSÃO}

\section{Chave para identificação dos táxons de Sapotaceae das restingas do estado do Pará}

1. Folhas alternas espiraladas

2. Nervuras intersecundárias estendendo-se até a metade da largura do limbo

3. Lobos da corola 6; estames 6, fixados na base do tubo; filetes congênitos com os estaminódios; ovário glabro

4. Estípulas persistentes; nervuras quaternárias evidentes na face adaxial Manilkara bidentata subsp. bidentata

4. Estípulas ausentes; nervuras quaternárias não evidentes na face adaxial.........Manilkara bidentata subsp. surinamensis

3. Lobos da corola 4-5; estames 4-5, fixados no meio do tubo; filetes não congênitos com os estaminódios; ovário densamente pubescente Manilkara triflora

2. Nervuras intersecundárias ultrapassando a metade da largura do limbo

5. Ramo glabro, pecíolo glabro; folhas com ápice obtuso ou emarginado; nervuras terciárias obscurecidas pelas quaternárias, não proeminentes ........... Manilkara paraensis

5. Ramo tomentoso ou puberulento; pecíolo puberulento; folhas com ápice acuminado ou arredondado; nervuras terciárias evidentes, proeminentes

6. Ramo tomentoso; folhas elípticas, oblanceoladas, obovadas ou lanceoladas, base cuneada; fruto piriforme ou globoso, pubescente Pouteria ramiflora

6. Ramo puberulento; folhas elípticas, oblongas, base obtusa ou inconspicuamente decorrente; fruto elipsóide, glabro Pouteria reticulata subsp. reticulata 1.

Folhas alternas dísticas, subopostas ou opostas decussadas 7. Folhas subopostas ou opostas decussadas; nervuras secundárias 15-23 pares; venação eucampdódroma a broquidódroma, bulada; nervuras terciárias evidentes; nervuras quaternárias evidentes, finamente areoladas; estames 5-6; estaminódios ausentes; ovário oblongo; fruto esparsamente pubescente ...... Pradosia schomburgkiana subsp. schomburgkiana 
7. Folhas alternas dísticas; nervuras secundárias 25-135 pares; venação craspedódroma a broquidódroma, não bulada; nervuras terciárias não evidentes, misturando-se com as secundárias; nervuras quaternárias não evidentes; estames 4-5; estaminódios 4-5; ovário umbulado, ovalado ou obovado; fruto glabro

8. Ramo puberulento; pecíolo pubescente ou glabro; nervuras secundárias 119-135 pares; corola com lobos 4-5; estames 4-5, fixados na regiáo mediana do tubo; estaminódios 4-5; ovário ovalado, lóculos 6; estilete 2.5-4 mm compr Micropholis venulosa

8. Ramo tomentoso; pecíolo tomentoso; nervuras secundárias 25-58 pares; corola com lobos 5; estames 5; fixados no ápice do tubo; estaminódios 5; ovário umbulado ou obovado, lóculos 5; estilete $0.7-2.0 \mathrm{~mm}$ compr Micropholis gnaphaloclados

\section{Descrição dos táxons}

Manilkara bidentata (A. de Candolle) Chevalier subsp. bidentata. Flora Neotropica 52: 61-64. 1990. (Figura 1).

Nome vernacular: Maparajuba ou Maparajuba-verdadeira

Arbusto ou árvore de até $4 \mathrm{~m}$. de altura. Ramo cilíndrico, marrom-escuro a cinza, glabro. Estípulas 2,5-4,5 mm compr., lanceoladas, esparsamente pubescentes, persistentes. Pecíolo 0,1-2 cm compr., canaliculado, glabro. Folhas 0,9-13,6 cm compr., 0,6-5,5 cm larg., alternas espiraladas, cartáceas a coriáceas, oblanceoladas, elípticas ou oblongas, glabras, ápice agudo ou emarginado, base cuneada a decorrente; nervuras secundárias 9-41 pares, buladas; intersecundárias estendendo-se até a metade da largura do limbo; nervuras terciárias obscurecidas pelas quaternárias, reticuladas; nervuras quaternárias evidentes na face adaxial, finamente areoladas; nervuras submarginais presentes; venação broquidódroma. Flores 2-4, em fascículos axilares ou terminais. Sépalas 0,9-4 mm compr., 0,5-1,1 mm larg., soldadas na base, lanceoladas, puberulentas no exterior, glabras no interior, ápice agudo a arredondado. Tubo da corola $0,6 \mathrm{~mm}$ compr., glabro; lobos 6, lanceolados; estames 6, inclusos, glabros, fixados na base do tubo; filetes $0,4-1 \mathrm{~mm}$ compr., congênitos com os estaminódios; anteras 0,3-1 mm compr., dorsifixa, lanceoladas a ovaladas. Estaminódios 6, 0,3-0,5 mm compr., glabros, lanceolados, ápice agudo. Ovário 1-1,5 mm compr., ovalado, glabro, lóculos 6; estilete 3-4 mm compr., cilíndrico, geralmente excedendo os estames. Fruto bacóide, 3-10 mm diâm., elipsóide ou globoso, glabro, ápice e base arredondado ou truncado, liso.

Distribuição geográfica: Bolívia, Brasil (AC, PA, RO, RR), Caribe, Colômbia, Equador, Guiana, Guiana Francesa, Peru, Suriname, Venezuela (Mobot 2012; Almeida Jr. 2012).

Material selecionado: Brasil. Pará: Maracanã, ilha de Maiaundeua-Algodoal, restinga, 10. II. 2003, fr., Lobato
2950 (MG); ibidem, dunas, 20-23. III. 1995, fr., Lobato 1027 (MG); ibidem, Fortalezinha, restinga, 03. VII. 1992, fl. \& bot., Lobato 517 (MG); ibidem, praia da Princesa, restinga, 23.VIII. 1999, fl. \& bot., Carreira 1410 (MG); ibidem, Mata do terreiro, restinga, 21. XII. 1993, fl., Bastos 1481; ibidem, floresta de restinga, 25. IX. 1993, fr., Bastos 1438 (MG); ibidem ilha do Marco, restinga, 12. I. 1992, fl. \& fr., Bastos 1146 (MG).

$\mathrm{Na}$ área de estudo, Manilkara bidentata subsp. bidentata diferencia-se das outras espécies por ser a única que apresenta estípulas persistentes. Nesse ambiente, o táxon ocorre na formação de dunas e floresta de restinga.

Manilkara bidentata subsp. surinamensis (Miq.) T.D. Penn. Flora Neotropica 52: 61-64. 1990. (Figura 2)

\section{Nome vernacular: Maparajuba}

Arbusto ou árvore de 3-6 m. de altura. Ramo cilíndrico, marrom-escuro a cinza, glabro. Estípulas ausentes. Pecíolo 0,6-2,2 cm compr., canaliculado, glabro. Folhas 3,4-14,1 cm compr., 0,6-4,5 cm larg., alternas espiraladas, cartáceas a coriáceas, oblanceoladas ou elípticas, glabras, ápice obtuso, emarginado ou raro agudo, base cuneada ou obtusa; nervuras secundárias numerosas, superficiais; intersecundárias estendendo-se até a metade da largura do limbo; nervuras terciárias e quaternárias não evidentes na face adaxial; venação broquidódroma. Flores 2-4, em fascículos axilares. Sépalas 0,8-5 mm compr., 0,5-1 mm larg., soldadas na base, lanceoladas, puberulentas no exterior, glabras no interior, ápice agudo a arredondado. Tubo da corola $0,5-0,7 \mathrm{~mm}$ compr., glabro; lobos 6, lanceolados; estames 6, inclusos, glabros, fixados na base do tubo; filetes $0,5-1 \mathrm{~mm}$ compr., congênitos com os estaminódios; anteras $0,25-1 \mathrm{~mm}$ compr., dorsifixa, lanceoladas a ovaladas. Estaminódios 6, 0,25-0,5 mm compr., glabros, lanceolados, ápice agudo. Ovário 0,9-1,5 mm compr., ovalado, glabro, lóculos 6; estilete $2-4 \mathrm{~mm}$ compr., cilíndrico, geralmente excedendo os estames. Fruto bacóide, 4-11 mm diâm., globoso, glabro, ápice e base arredondados ou truncados, liso.

Distribuição geográfica: Bolívia, Brasil (AC, AM, AP, PA, RR), Caribe, Colômbia, Equador, Guiana, Guiana Francesa, Peru, Suriname e Venezuela (Mobot 2012; Almeida Jr. 2012).

Material selecionado: Brasil. Pará: Maracanã, praia da Marieta, 23. VIII. 2007, fl., Rocha et al. 739 (MG); ibidem, Ilha de Maiandeua, Camboinha, 24. XI. 1993, fr., Bastos et al. 1427 (MG); Salinópolis, praia do Atalaia, 20.VIII.2007, fl., Rocha et al. 683 (MG).

$\mathrm{Na}$ área de estudo, Manilkara bidentata subsp. surinamensis é confundida com Manilkara bidentata subsp. bidentata, entretanto diferencia-se desta última pela ausência de estípulas e nervuras quaternárias não evidentes na face adaxial. Nesse ambiente, o táxon ocorre em paleodunas e floresta de restinga. 
Manilkara triflora (F. Allemão) Monach. Phytologia 4(2): 107. 1952. (Figura 1).

\section{Nome vernacular: Maçarandubarana}

Arbusto ou árvore de até $5 \mathrm{~m}$. de altura. Ramo cilíndrico, marrom-acinzentado, glabro. Estípulas caducas. Pecíolo 0,30,7 cm compr., canaliculado, glabro. Folhas 2-7 cm compr.; 1,1-3 cm larg., alternas espiraladas, coriáceas, oblanceoladas, glabras, ápice emarginado ou raramente obtuso, base cuneada; nervuras secundárias 12-16 pares, buladas; intersecundárias estendendo-se até a metade da largura do limbo; nervuras terciárias evidentes, proeminentes na face adaxial; nervuras quaternárias não evidentes, não areoladas; nervuras submarginais presentes; venação eucampdódroma à broquidódroma. Flores 1-3, em fascículos axilares. Sépalas 2-3 mm compr., 1-2 mm larg., soldadas na base, lanceoladas, puberulentas no exterior, puberulentas a glabras no interior, ápice agudo a obtuso. Tubo da corola 1,2-2 mm compr., glabro, lobos 4-5, lanceolados a obtusos; estames 4-5, inclusos, glabros, fixados na regiáo mediana do tubo; filetes $0,3-1$ mm compr., não congênitos com os estaminódios; anteras 0,3-1,2 mm compr., dorsifixa, lanceoladas à sagitiformes. Estaminódios 4-6, 0,4-1 mm compr., glabros, lanceolados, ápice agudo. Ovário 0,6-1,2 $\mathrm{mm}$ compr., umbulado ou ovalado, densamente pubescente, 5-6 lóculos; estilete 0,4-1,2 mm compr., cilíndrico, geralmente excedendo os estames. Fruto bacóide, 4-10 mm diâm., elipsóide, glabro, ápice arredondado a truncado, apiculado; base arredondada, liso.

Distribuição geográfica: Brasil: CE, PA, PI, BA, MG, RN (Mobot 2012; Almeida Jr. 2012)

Material selecionado: Brasil. Pará: Maracaná, ilha de Maiaundeua-Algodoal, campo de dunas, 11. I. 1992, fr., Bastos 1137 (MG); ibidem, formação aberta de moitas, 25. IX. 1993, bot., Bastos 1423 (MG); ibidem, praia da Marieta, restinga, floresta de restinga, 07. IX. 1994, fr., Bastos 1810 (MG); ibidem, praia da Princesa, 12. IV. 1991, fr., Bastos 744 (MG).

Nas restingas do Pará, Manilkara triflora pode ser confundida com Manilkara paraensis (Huber) Standl., porém diferencia-se desta por apresentar nervuras intersecundárias curtas, estendendo-se até a metade do limbo. Trata-se de uma espécie endêmica do Brasil, que no litoral paraense, pode ser encontrada na formação aberta de moitas, campo de dunas e floresta de restinga.

Manilkara paraensis (Huber) Standl. Tropical Woods 34: 41. 1933. (Figura 1).

Nome vernacular: Maçarandubinha

Árvore de $4 \mathrm{~m}$. de altura. Ramo cilíndrico, marromacinzentado, glabro. Estípulas caducas. Pecíolo 0,4-1,2 cm compr., canaliculado, glabro. Folhas 1,5-7,8 cm compr., 0,7-3 cm larg., alternas espiraladas, cartáceas a coriáceas, oblanceoladas, glabras, ápice obtuso ou emarginado, base cuneada; nervuras secundárias 14-36 pares, arqueadas, buladas; inter-secundárias ultrapassando a metade da largura do limbo; nervuras terciárias obscurecidas pelas quaternárias, não proeminentes; nervuras quaternárias evidentes, finamente areoladas; nervuras submarginais presentes, venação broquidódroma. Flores 2-7, em fascículos axilares. Sépalas 2-4 mm compr., 0,8-3,2 mm larg., soldadas na base, lanceoladas, puberulentas no exterior, puberulentas a glabras no interior, ápice agudo a arredondado. Tubo da corola 0,7-2,4 mm compr., glabro; lobos 5-6, lanceolados; estames 5-6, inclusos, glabros, fixados na base do tubo; filetes $0,3-1,3 \mathrm{~mm}$ compr., congênito com os estaminódios; anteras 0,3-1,4 mm compr., dorsifixas, lanceoladas. Estaminódios 5-6, 0,4-0,5 mm compr., glabros, lanceolados, ápice agudo a arredondado. Ovário 0,5-0,8 mm compr., obovado a ovalado, glabro, lóculos 5-6; estilete 3-4 mm compr., cilíndrico, excedendo os estames. Fruto bacóide, 3-11,5 mm diâm., elipsóide ou subgloboso, glabro, ápice e base arredondados ou truncados, liso.

Distribuição geográfica: Brasil (MA, MT, PA), Guiana Francesa, Suriname (Mobot 2012; Almeida Jr. 2012).

Material selecionado: Brasil. Pará: Maracanã, ilha de Maiaundeua-Algodoal, dunas, 01. VII. 1992, fl. \& fr., Lobato 471 (MG).

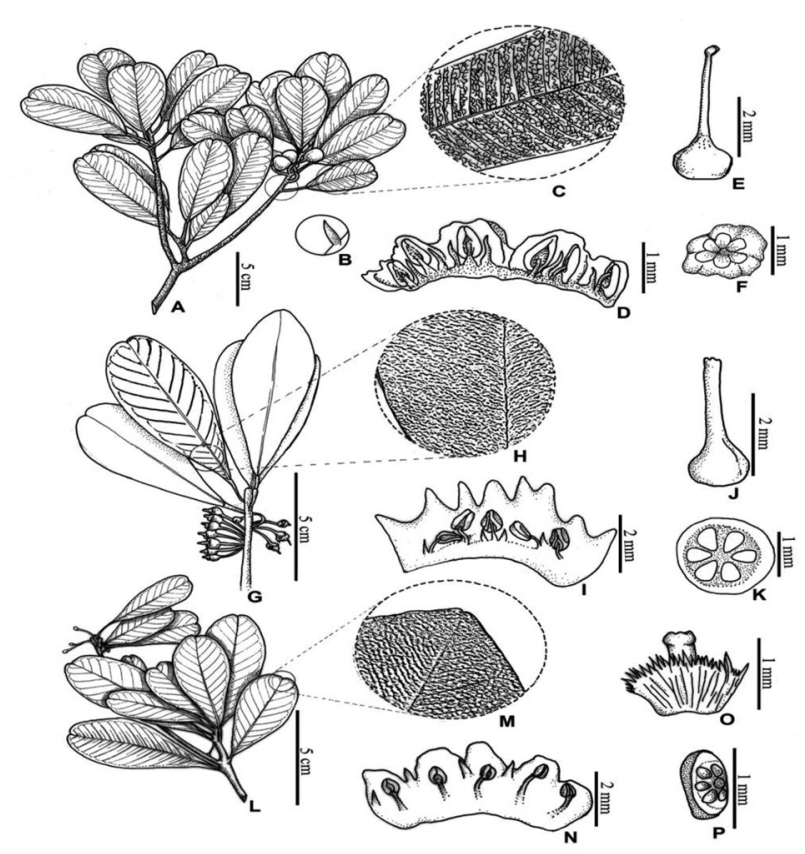

Figura 1 - Manilkara bidentata subsp. bidentata: A. ramo; B. estípula; C. detalhe das nervuras; D. corola com estames e estaminódios; E. gineceu; F. corte transversal do ovário evidenciando os lóculos. Manilkara paraensis: G. ramo; H. detalhe das nervuras; I. corola com estames e estaminódios; J. gineceu; K. corte transversal do ovário evidenciando os lóculos. Manilkara triflora: L. ramo; M. detalhe das nervuras; $N$. corola com estames e estaminódios; 0. gineceu; P. corte transversal do ovário evidenciando os lóculos. 
Nas restingas do Pará, Manilkara paraensis diferenciase das outras espécies do gênero por apresentar nervuras intersecundárias longas, estendendo-se além da metade do limbo. Nessa restinga, a espécie foi encontrada na formação campo de dunas.

Pouteria ramiflora (Mart.) Radlk. Sitzungsberichte der Mathematisch-Physikalischen Classe (Klasse) der K. B. Akademie der Wissenschaften zu München 12: 333. 1882. (Figura 2)

Nome vernacular: Abiu-cutite

Árvore de até $8 \mathrm{~m}$. de altura. Ramo cilíndrico, acinzentado, tomentoso. Estípulas ausentes. Pecíolo 0,4-1,5 cm compr., canaliculado, puberulento. Folhas 1,3-14,2 cm compr., 1-7 cm larg., alternas espiraladas, cartáceas a coriáceas, elípticas, oblanceoladas, obovadas ou lanceoladas, glabras a pubescentes, ápice acuminado ou arredondado, base cuneada; nervuras secundárias 10-16 pares, arqueadas, buladas; inter-secundárias ultrapassando a metade da largura do limbo; nervuras terciárias evidentes, proeminentes; nervuras quaternárias evidentes, finamente areoladas; nervuras submarginais presente; venação broquidódroma. Flores 7-14 em um fascículo, ao longo do ramo. Sépalas 1,1-2 mm compr., 0,8-1,5 mm larg., soldadas na base, obovadas, puberulentas no exterior, glabras no interior, ápice obtuso a arredondado. Tubo da corola 2,1-3 mm compr., glabro; lobos 4, ovalados a orbiculares; estames 4 , inclusos, glabros, fixados na base do tubo; filetes $0,4-1,2 \mathrm{~mm}$ compr., congênitos com os estaminódios; anteras 0,3-0,7 mm compr., dorsifixas, lanceoladas. Estaminódios 4, 0,4-0,5 mm compr., glabros, lanceolados a subulados, ápice arredondado a truncado. Ovário 0,5-2 mm compr., umbulado ou ovalado, densamente puberulento, lóculos 2; estilete 0,5-1,7 mm compr., cilíndrico, geralmente excedendo os estames. Fruto bacóide, 5-12 mm diâm., piriforme ou globoso, pubescente, ápice arredondado ou truncado, base cônica, liso.

Distribuição geográfica: Bolívia, Brasil (AM, BA, CE, DF, GO, MA, MS, MG, MT, PA, PI, PE, RJ, RO, SP, TO), Paraguai (Mobot 2012; Alves-Araujo 2012).

Material selecionado: Brasil. Pará: Maracanã, ilha de Maiaundeua-Algodoal, praia da Princesa, restinga, 17. VI. 1994, fl. \& bot., Bastos 1723 (MG); ibidem, 19-25. VIII.1994, fl. \& bot., Bastos 1731 (MG); ibidem, Rocinha, 21. IX. 1993, fl. \& bot., Bastos 1399 (MG); ibidem, praia da Marieta, floresta de restinga, 23. VIII. 2007, fl. \& bot., Rocha 727 (MG); ibidem, ilha do Marco, restinga, floresta de restinga, 12. I. 1992, fl. \& bot., Bastos 1144 (MG); ibidem, ilha de Fortalezinha, restinga, 05-20. XII. 1999, Lobato 2492 (MG).

Pouteria ramiflora diferencia-se das demais espécies de Sapotaceae na área, por ser a única que apresenta ovário com dois lóculos. Ocorre predominantemente na formação floresta de restinga.
Pouteria reticulata (Engl.) Eyma subsp. reticulata. Recueil des Travaux Botaniques Néerlandais 33: 183. 1936. (Figura 2)

Nome vernacular: Abiu da praia

Árvore ou arbusto de até $4 \mathrm{~m}$. de altura. Ramo cilíndrico, acinzentado, puberulento. Estípulas ausentes. Pecíolo 0,5$2,1 \mathrm{~cm}$ compr., canaliculado, puberulento. Folhas $4-17 \mathrm{~cm}$ compr., 1,5-6,5 cm larg., alternas espiraladas, cartáceas a coriáceas, oblongas, glabras, ápice acuminado, base obtusa ou inconspicuamente decorrente; nervuras secundárias 9-16 pares, arqueadas, superficiais; intersecundárias ultrapassando a metade da largura do limbo; nervuras terciárias evidentes, proeminentes; nervuras quaternárias evidentes; nervuras submarginais presente; venação broquidódroma. Flores ausentes. Fruto bacóide, 6-11 mm diâm., elipsóide, glabro, ápice arredondado, base arredondada, liso.

Distribuição geográfica: Belize, Bolívia, Brasil (AC, AP, AM, BA, CE, GO, MA, MT, MG, PA, RJ, RO, RR e SP), Colômbia, Costa Rica, Equador, Guiana Francesa, Guatemala, Honduras, México, Nicarágua, Panamá, Peru, Suriname e Venezuela (Mobot 2012; Alves-Araujo 2012).

Material selecionado: Brasil. Pará: Salinópolis, praia de Atalaia, dunas, 09. III. 1989, fr., Carreira et al. 1088 (MG).

Pouteria reticulata subsp. reticulata diferencia-se das demais cogenéricas aqui tratadas por apresentar folhas oblongas com base obtusa ou inconspicuamente decorrente. Essa subespécie foi encontrada somente em dunas.

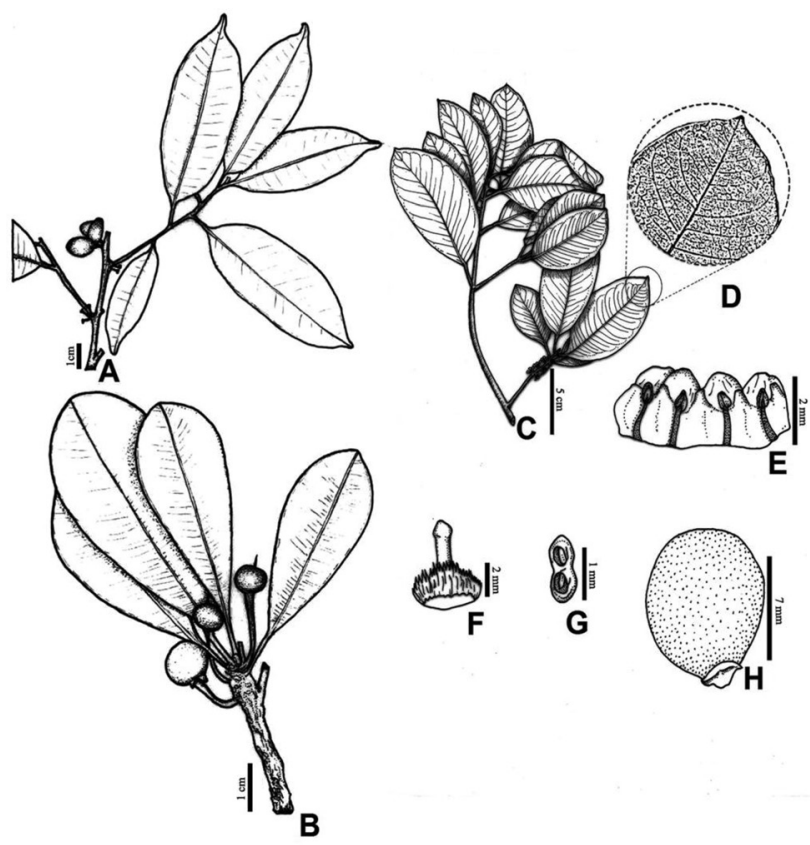

Figura 2 - Pouteria reticulata subsp. reticulata: A. ramo. Manilkara bidentata subsp. surinamensis: B. ramo. Pouteria ramiflora: C. ramo; D. detalhe das nervuras; E. corola com estames e estaminódios; F. gineceu; G. corte transversal do ovário mostrando os lóculos; H. fruto. 
Pradosia schomburgkiana (A. de Candolle) Cronquist subsp. schomburgkiana. Flora Neotropica 52: 659-660. 1990. (Figura 3).

\section{Nome vernáculo: Casca-doce}

Arbusto ou árvore de até $4 \mathrm{~m}$. de altura. Ramo cilíndrico, acinzentado a marrom, puberulento a glabro. Estípulas ausentes. Pecíolo 0,3-1,4 cm compr., canaliculado, puberulento. Folhas 2-12,3 cm compr., 1,1-5,9 cm larg., subopostas ou opostas decussadas, coriáceas, oblanceoladas, elípticas a oblongas, glabras, ápice agudo ou emarginado, base cuneada à decorrente; nervuras secundárias 15-23 pares, buladas; inter-secundárias ultrapassando a metade da largura do limbo; nervuras terciárias evidentes; nervuras quaternárias evidentes, finamente areoladas; nervuras submarginais presentes, venação eucampdódroma a broquidódroma, buladas. Flores 6-20, em racemos axilares ou terminais. Sépalas 1,4-2,9 mm compr., 0,7-1,3_mm larg., soldadas na base, ovaladas a orbiculares, esparsamente puberulentas no exterior, puberulentas a glabras no interior, ápice obtuso a arredondado. Tubo da corola 0,8-4,5 mm compr., glabro; lobos 5-6, lanceolados a ovalados; estames 5-6, inclusos, glabros, fixados na região mediana do tubo; filetes $0,4-0,8 \mathrm{~mm}$ compr.; anteras 0,3-1 mm compr., dorsifixas, lanceoladas a ovaladas. Estaminódios ausentes. Ovário 0,8-1,6 mm compr., oblongo, puberulento, lóculos 5-6; estilete 0,3-1,4 mm compr., cilíndrico, geralmente excedendo os estames. Fruto bacóide, 6-10 mm diâm., elipsóide ou obovóide, esparsamente
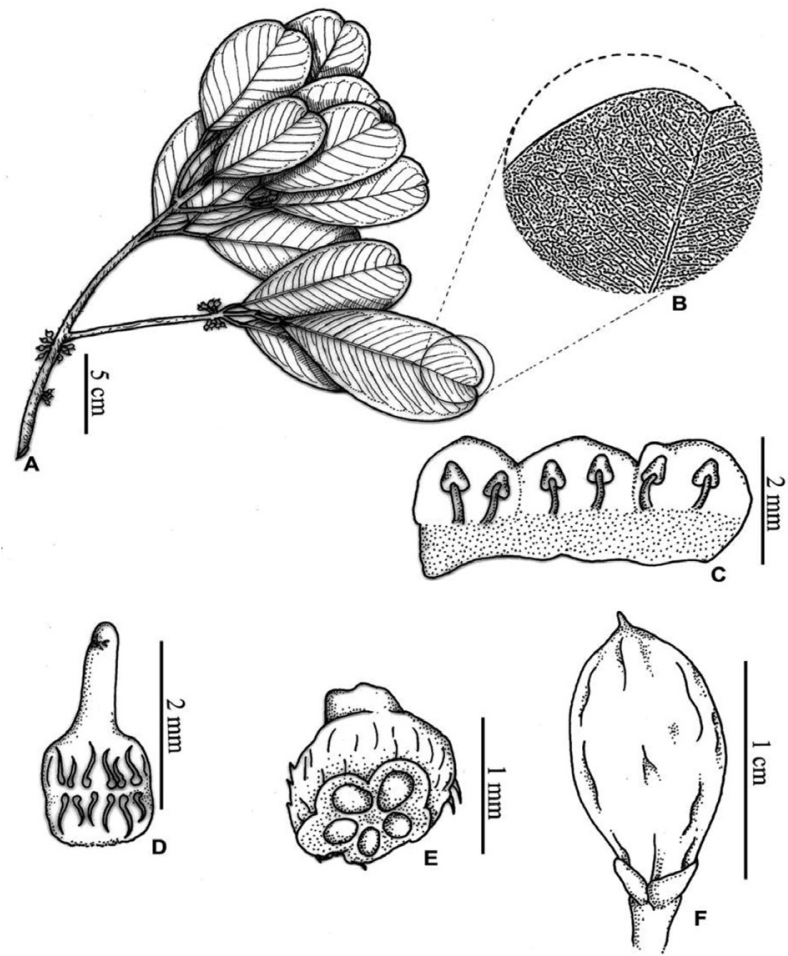

Figura 3 - Pradosia schomburgkiana subsp. schomburgkiana: A. ramo; B. detalhe das nervuras; $C$. corola com estames; $D$. gineceu; $E$. corte transversal do ovário mostrando os lóculos; F. fruto. pubescente, ápice arredondado, base arredondada ou cônica, liso.

Distribuição geográfica: Brasil (AM, PA, RR), Colômbia, Guiana, Suriname, Venezuela (Mobot 2012; Carneiro et al. 2012).

Material selecionado: Brasil. Pará: Maracanã, ilha de Maiaundeua-Algodoal,Vila de Algodoal, 01. III. 1988, fl., Bastos 521 (MG); ibidem, floresta de restinga, 15. II. 2002, fl. \& bot., Lobato 2712 (MG); ibidem, formação aberta de moitas, 30. I. 1988, fl. \& bot., Araújo 8492 (MG).

Pradosia schomburgkiana subsp. schomburgkiana se diferencia das outras das restingas do Pará por ser a única que apresenta filotaxia oposta decussada ou suboposta. A subespécie ocorre nas formaçóes aberta de moitas e floresta de restinga.

\section{Micropholis venulosa (Mart. \& Eichler) Pierre. Notes Botaniques Sapotacees 2: 40. 1891. (Figura 4).}

Nome vernacular: rosadinho

Arbusto ou árvore de até $6 \mathrm{~m}$. de altura. Ramo cilíndrico, cinza a cinza-esbranquiçado, puberulento. Estípulas ausentes. Pecíolo 0,3-0,7 cm compr., canaliculado, pubescente ou glabro. Folhas $1.5-8 \mathrm{~cm}$ compr., $1.3-4.1 \mathrm{~cm}$ larg., alternas dísticas, cartáceas a coriáceas, elípticas, lanceoladas ou raramente oblongas, glabras, ápice atenuado, acuminado ou emarginado, base cuneada a decorrente; nervuras secundárias 119-135 pares, não buladas; inter-secundárias ultrapassando a metade da largura do limbo; nervuras terciárias não evidentes, misturando-se com as secundárias; quaternárias não evidentes; nervuras submarginais ausentes; venação craspedódroma a broquidódroma, não bulada. Flores 3-5, em fascículos axilares. Sépalas 2-5 mm compr., 0,6-2 mm larg., soldadas na base, ovaladas a lanceoladas, puberulentas no exterior, puberulentas a glabras no interior, ápice agudo a arredondado. Tubo da corola $3 \mathrm{~mm}$. compr., glabro; lobos 4-5, lanceolados; estames 4-5, inclusos, glabros, fixados na região mediana do tubo; filetes $0,4-0,7 \mathrm{~mm}$ compr., congênitos com os estaminódios; anteras 0,3-1 mm compr., dorsifixas, lanceoladas a ovaladas. Estaminódios 4-5, 0,3-0,5 mm compr., glabros, lanceolados, ápice agudo. Ovário 0,5-1 mm compr., ovalado, puberulento a glabro, lóculos 6; estilete 2,5-4 mm compr., cilíndrico, excedendo os estames. Fruto bacóide, 4-12 mm diâm., subgloboso a elipsóide, glabro, ápice e base agudos ou arredondados, liso.

Distribuição geográfica: Bolívia, Brasil (AC, AP, AM, BA, DF, GO, MA, MG, MS, MT, PA, RO), Colômbia, Costa Rica, Equador, Guiana Francesa, Guiana, Panamá, Peru, Suriname, Venezuela (Mobot 2012; Carneiro et al. 2012).

Material selecionado: Brasil. Pará: Maracanã, ilha de Maiaundeua-Algodoal, 11. XIII. 1992, bot., Bastos 1345 (MG); ibidem, formação aberta de moitas, 30. I. 1988, fr., 
Araúijo 8493 (MG); ibidem, restinga litorânea arenosa, floresta de restinga, 01. III. 1988, fr., Bastos 525 (MG); ibidem, ilha do Marco, restinga, 13. I. 1992, fl. \& fr., Bastos 1178 (MG); ibidem, 12. I. 1992, bot., Bastos 1148 (MG); ibidem, Vila da Mota, restinga da Marieta, floresta de restinga, 17. XI. 1994, fl. \& bot., Lobato 905 (MG); ibidem, praia da Marieta, restinga, floresta de restinga, 07. IX. 1994, fl. \& bot. Bastos 1773 (MG).

Em Algodoal/Maiandeua, Micropholis venulosa diferenciase das outras por ser a única que apresenta 119-135 pares de nervuras secundárias. No ambiente, a espécie ocorre com mais frequência na floresta de restinga, podendo também ser encontrada na formaçáo aberta de moitas.

Micropholis gnaphaloclados (Mart.) Pierre. Symbolae Antillarum 5: 130. 1904. (Figura 4)

Nome vernacular: Prejuí

Arbusto de $1 \mathrm{~m}$. de altura. Ramo cilíndrico, acinzentado, tomentoso. Estípulas ausentes. Pecíolo 0,2-0,7 cm compr., canaliculado, tomentoso. Folhas 1,5-6,8 cm compr., 1,5-3 $\mathrm{cm}$ larg., alternas dísticas, cartáceas a coriáceas, oblanceoladas, elípticas a orbiculares, glabras a esparsamente pubescentes, ápice agudo ou emarginado, base cuneada; nervuras secundárias 25-58 pares, não buladas; intersecundárias ultrapassando a metade da largura do limbo; nervuras terciárias não evidentes; nervuras quaternárias não evidentes; nervuras submarginais ausentes, venação craspedódroma a broquidódroma. Flores 2-5, em fascículos ao longo do ramo. Sépalas 2,5-3,5 mm compr., 0,8-2 mm larg., soldadas na base, ovaladas, pubescentes no exterior, glabras no interior, ápice agudo a obtuso. Tubo da corola 2,6-3,2 mm compr., glabro; lobos 5, lanceolados a obtusos; estames 5, inclusos, glabros, fixados no ápice do tubo; filetes $0,3-1 \mathrm{~mm}$ compr., congênitos com os estaminódios; anteras 0,3-1 mm compr., dorsifixas, lanceoladas a ovaladas. Estaminódios 5, 0,6-1,3 mm compr., glabros, lanceolados, ápice agudo a arredondado. Ovário 0,6-2,2 mm compr., umbulado ou obovado, densamente puberulento, lóculos 5; estilete 0,7-2,0 $\mathrm{mm}$ compr., cilíndrico, geralmente excedendo os estames. Fruto bacóide, 5-8 mm diâm., elipsóide, esparsamente puberulento no ápice, ápice e base arredondados, liso.

Distribuição geográfica: Bolívia, Brasil: BA, MT, MG, PE (Mobot 2012; Carneiro et al. 2012) e PA.

Material selecionado: Brasil. Pará: Maracanã, ilha de Maiaundeua-Algodoal, APA de Algodoal, floresta de restinga, 05. X. 2006, fl. \& fr., Furtado 18 (MG).

$\mathrm{Na}$ restinga de Algodoal/Maiandeua, Micropholis gnaphaloclados pode ser confundido com Micropholis venulosa, porém se distingui desta por apresentar ramo tomentoso, nervuras secundárias $25-58$ pares, corola com 5 lobos; estames 5; estaminódios 5; ovário umbulado ou obovado e lóculos
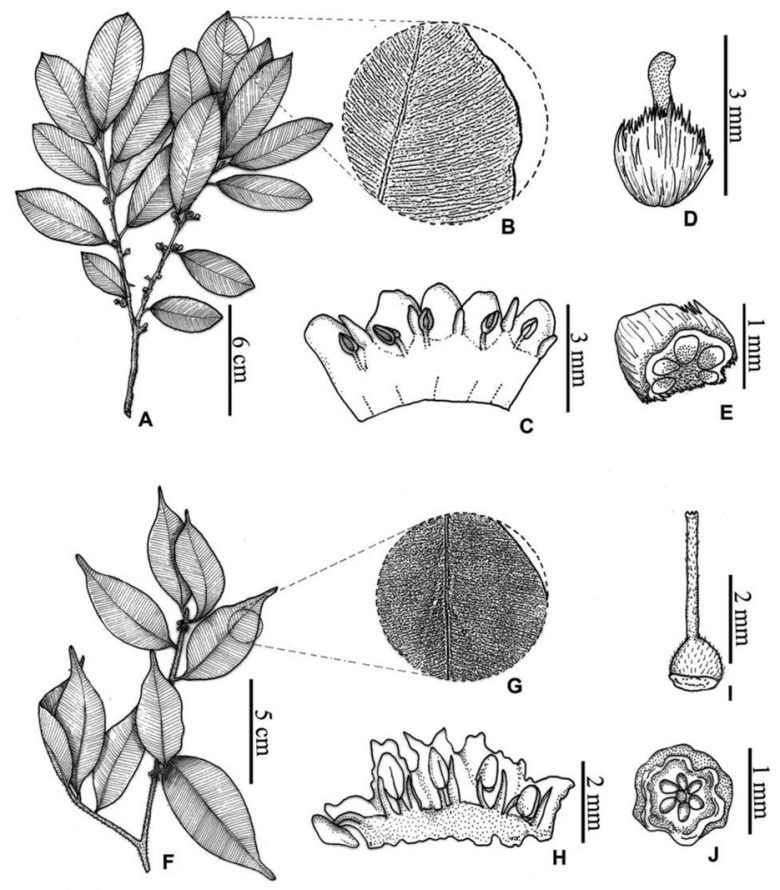

Figura 4 - Micropholis gnaphaloclados: A. ramo; B. detalhe das nervuras; C. corola com estames e estaminódios; $D$. gineceu; $E$. corte transversal do ovário mostrando os lóculos. Micropholis venulosa: F. ramo; G. detalhe das nervuras; H. corola com estames e estaminódios; I . gineceu; J. corte transversal do ovário evidenciando os lóculos.

5. A espécie foi encontrada somente na formação floresta de restinga.

\section{CONCLUSÕES}

Nas espécies de Sapotaceae das restingas do estado do Pará, os principais caracteres utilizados para a separação dos táxons foram nervuras, lóculos, estaminódios e a filotaxia. Entre as espécies dessa família, Micropholis gnaphaloclados é uma nova ocorrência. O gênero Manilkara Adans. foi o mais representativo com duas espécies e uma subespécie, sendo Manilkara triflora a mais abrangente, ocorrendo desde campo de dunas até floresta de restinga. A formação floresta de restinga foi a mais representativa, apresentando seis das sete espécies registradas na área.

\section{AGRADECIMENTOS}

Ao Programa Institucional de Bolsas de Iniciação Científica (PIBIC), pela concessão da bolsa. Ao Museu Paraense Emílio Goeldi, por ceder o laboratório de taxonomia. À Empresa Brasileira de Pesquisa Agropecuária (EMBRAPA Amazônia Oriental), por conceder imagens dos exemplarestipo do Herbário IAN. 


\section{BIBLIOGRAFIA CITADA}

Almeida Jr., E.B. 2012. Manilkara in: Lista de Espécies da Flora do Brasil, Jardim Botânico do Rio de Janeiro, (http://floradobrasil. jbrj.gov.br/2012/FB024786). Acesso em 12/05/2012.

Alves-Araujo, A. 2012. Pouteria in: Lista de Espécies da Flora do Brasil, Jardim Botânico do Rio de Janeiro, (http://floradobrasil. jbrj.gov.br/2012/FB032761). Acesso em 12/05/2012.

Amaral, D.D.; Prost, M.T.; Bastos, M.N.C; Costa Neto, S.V.; Santos, J.U.M. 2008. Restingas do litoral amazônico, estados do Pará e Amapá, Brasil. Boletim do Museu Paraense Emílio Goeldi, 3: 35-67.

APG III. 2009. An update of the Angiosperm Phylogeny Group classification for the orders and families of flowering plants: APG III. Botanical Journal of the Linnean Society 161: 105-121.

Bastos, M.N.C.; Senna, C.; Costa Neto, S.V. 2002. Comunidades vegetais em paisagens litorâneas do estado do Pará: as restingas do Crispim e Algodoal, p. 239-258. In: Furtado, L.G.; Quaresma, H.D.A.B. Gente e ambiente no mundo da pesca artesanal. Museu Paraense Emílio Goeldi, Belém, Pará.

Carneiro, C.E.; Almeida Jr., E.B.; Alves-Araujo, A. 2012. Sapotaceae in: Lista de Espécies da Flora do Brasil. Jardim Botânico do Rio de Janeiro, (http://floradobrasil.jbrj.gov.br/2012/FB039538). Acesso em 12/05/2012.

Hickey, L.J. 1973. Classification of the arquitecture of dicotyledonous leaves. American Journal of Botany, 60: 17-33.
Margalho, L.F.; Rocha, A.E.S.; Secco, R.S. 2009. Rubiaceae Juss. da restinga da APA de Algodoal/Maiandeua, Maracanã, Pará, Brasil. Boletim Museu Paraense Emilio Goeldi, 4: 303-339.

Mobot, 2012. Missouri Botanical Garden, W3MOST, (http:// www.mobot.mobot.org/W3T/Search/vast.html) Acesso em 10/05/2012.

Pennington, T.D. 1990. Monograph of Sapotaceae. Flora Neotropica, 52: $1-770$.

Rizzini, C.T. 1977. Sistematização terminológica da folha. Rodriguesia, 29: 103-125.

Rocha, A.E.S.; Bastos, M.N.C. 2004. Flora fanerogâmica das restingas do estado do Pará: APA de Algodoal/Maiandeua. II Eriocaulaceae P. Beauv. ex Desv. Hoehnea, 31: 103-111.

Rosário, A.S.; Secco, R.S.; Amaral, D.D.; Santos, J.U.M.; Bastos, M.N.C. 2005. Flora fanerogâmica das restingas do estado do Pará: ilhas de Algodoal e Maiandeua - 2. Myrtaceae R. Br. Boletim do Museu Paraense Emílio Goeldi, 1: 31-48.

Sousa, J.S.; Bastos, M.N.C.; Rocha, A.E.S. 2009. Mimosoideae (Leguminosae) do litoral paraense. Acta Amazonica, 39: 799-812.

Vicente, A.C.A.; Macedo, E.G.; Santos, J.U.M.; Potiguara, R.V.; Bastos, M.N.C. 1999. Flora Fanerogâmica das Restingas do Estado do Pará: ilhas de Algodoal 1 - família Turneraceae A.P. de Candolle. Boletim do Museu Paraense Emílio Goeldi, 15: 173-198.

Recebido em:20/05/12

Aceito em:05/07/2012 